\title{
Spatial distribution of a spherical gall (Hymenoptera, Eulophidae) on Caryocar brasiliense (Caryocaraceae)
}

\author{
Germano Leão Demolin Leite ${ }^{1,2}$, Vinicius de Abreu D’Ávila ${ }^{1}$, Vinicius Matheus Cerqueira ${ }^{1}$, \\ Aline Fonseca do Nascimento ${ }^{1} \&$ G. Wilson Fernandes ${ }^{3}$
}

\author{
'Insetário G. W. G. de Moraes, Universidade Federal de Minas Gerais, Av. Universitária 1000, B. Universitário, Caixa Postal 135. $39404-006$ Montes \\ Claros-MG, Brasil. gldleite@ig.com.br \\ ${ }^{2}$ Corresponding author. \\ ${ }^{3}$ Ecologia Evolutiva \& Biodiversidade, Universidade Federal de Minas Gerais, Caixa Postal 486, 0161-970 Belo Horizonte-MG, Brasil. \\ gw.fernandes@gmail.com
}

\begin{abstract}
Spatial distribution of a spherical gall (Hymenoptera, Eulophidae) on Caryocar brasiliense (Caryocaraceae). We obtained the first data on spatial distribution of a spherical galling insect (Hymenoptera, Eulophidae) at the Caryocar brasiliense Camb. (Caryocaraceae) tree level. This work was developed in two pastures in Montes Claros, Minas Gerais State, Brazil. The areas studied were: pasture 1 (in activity) and pasture 2 (abandoned pasture = savanna in recovery). We evaluated the distribution of spherical galls in: foliage orientation (slope), among leaves (border and interior of the tree crown), among leaflets (right, central, left), distal, median, and proximal as well as border, central area, and adjacent to the mid leaf vein of the leaflet, and difference between areas in 10 infested trees per area. The smaller number of spherical gall/leaflet was observed in pasture 1 than in pasture 2 . More spherical galls were found on the northern in pasture 1, but in the pasture 2, the lower spherical galls were observed on the northeast than other slopes. The average number of spherical galls did not differ statistically among the three leaflets of $C$. brasiliense in pasture 2. However, in pasture 1, we observed highest number of spherical galls in the central leaflet. More spherical galls were found in the border than interior of the tree crown. The average number of spherical galls did not differ statistically among the longitudinal region on leaflet of $C$. brasiliense. The spherical gall insect preferred to colonize the leaf margin than the central portion or near mid vein on transversal regions on a leaflet.
\end{abstract}

KEYWORDS. Cerrado; galling insects; insect distribution; pequi.

RESUMO. Distribuição espacial da galha esférica (Hymenoptera, Eulophidae) em Caryocar brasiliense (Caryocaraceae). Foi descrito, pela primeira vez, a distribuição espacial da galha esférica (Hymenoptera, Eulophidae) em árvores de Caryocar brasiliense Camb. (Caryocaraceae). Este trabalho foi desenvolvido em duas pastagens em Montes Claros, Estado de Minas Gerais, Brasil. As áreas estudadas foram: pastagem 1 (em atividade) e pastagem 2 (pastagem abandonada = cerrado em recuperação). Foi avaliada a distribuição de galhas esféricas em relação a: orientação das folhas no dossel, entre folhas (na borda ou no interior da copa da árvore), entre folíolos (direito, central, esquerdo), regiões distal, mediano, e proximal bem como na margem, área central e próximo à nervura central dos folíolos, e a diferença entre pastagens em 10 árvores infestadas por área. O menor número de galhas esféricas/ folíolo foi observado na pastagem 1 do que na pastagem 2. Mais galhas esféricas foram encontradas na face norte em pastagem 1, mas na pastagem 2, o menor número destas galhas foi observado nesta face (norte). O número médio de galhas esféricas não diferiu estatisticamente entre os folíolos de C. brasiliense na pastagem 2. Entretanto, na pastagem 1, foi observado maior número de galhas esféricas no folíolo central. Mais galhas esféricas foram encontradas na borda do que no interior da copa das árvores. O número médio de galhas esféricas não diferiu estatisticamente entre as regiões longitudinais dos folíolos de C. brasiliense. Entretanto, esse inseto galhador preferiu colonizar a margem dos folíolos à parte central ou próximo da nervura central dos folíolos.

PALAVRA-CHAVE. Cerrado; distribuição de inseto; inseto galhador; pequi.

Insect galls are known to distribute differentially within host organs. Many galling larva achieve higher density, size, and even higher fitness performance at the proximal portion compared to more distal portion of the leaf due to be the more rapid and efficient interception of plant photosynthates at the leaf base (Whitham 1978; Auslander et al. 2003). In a similar way, galls can be also more abundant and larger at the basal portion of the stems of its host plant where galls reach larger sizes perhaps due to stronger sinks in this region of the plant as showed by De Souza et al. (1998, 2001). Some insect galls can attack preferentially to leaf margin due to extrafloral nectarines found in this region, attracting ants and consequently reducing parasitism and predation (Oliveira 1997; Leite et al. 2009).

Insect galls may also distribute differentially between habitats as well as within the host crown. Plants in sunny habitats are known to support higher density of galls compared to plants in shaded habitats (Hartman 1984; Fernandes \& Price 1992; Auslander et al. 2003; Leite et al. 2009). The abundance of lepidopteran gall on Tetradymia DC. (Asteraceae) was higher on the sunlight-exposed foliage (Hartman 1984). Differential sun exposure may influence the quality of the host plant tissue as well as the gall tissue or even the plant ability to find and elicit induced responses to 
the invading organism (Fernandes et al. 2000, 2005). Furthermore, natural enemies could also be strong selective forces against galling on more favorable, shaded habitats (Fernandes \& Price 1992). Therefore, differential selection could lead to female preference and larval performance for foliage in sunny habitats.

Caryocar brasiliense Camb. (Caryocaraceae) is one of the most common and important plant species in the dry and harsh semi arid vegetation of Brazil, called cerrado (Leite $e t$ al. 2006a). It is host to a large number of invertebrate and vertebrate herbivores (Oliveira 1997; Leite et al. 2006b, 2011) as the gall insects (Leite et al. 2007, 2009), showing four species of leaf galls in the cerrado of northern Minas Gerais State, Brazil.

In an effort to initiate ecological studies in this system, we obtained the first data on spatial distribution of a spherical galling insect (Hymenoptera, Eulophidae) (Fig. 1) at the tree level. This gall is spheroid with $1.61 \mathrm{~mm}^{2}$ of diameter, without hairs, and its color is brown (Fig. 1). As C. brasiliense has three leaflet compound leaves we asked whether gall abundance would differ among the leaflets on a single leaf. We observed the effect of foliage slope orientation on gall abundance. A third question addressed the distribution of the galls on the leaves along the host stem (within tree). Because the grouping of galls on a given leaf portion may indicate site preference (Whitham 1978), we analyze the within leaf (longitudinal) distribution of galls as well as addressed the transversal zonation of spherical galls within leaves, and finally the differences between areas.

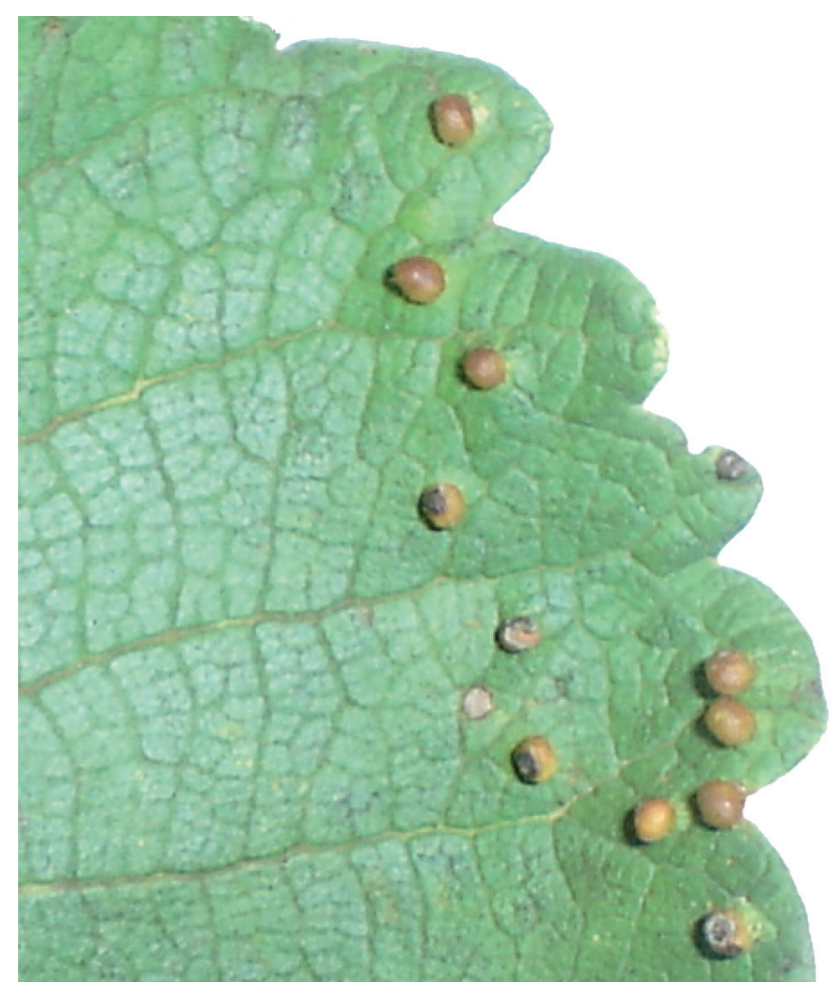

Fig. 1. Spheric galls on Caryocar brasiliense leaflet.

\section{MATERIAL AND METHODS}

This work was developed in two pastures (prior savanna) of the Municipality of Montes Claros, Minas Gerais State, Brazil in April, June, August and October 2006, with the averages temperature were $22.5,19.0,22.3$ and $23.5^{\circ} \mathrm{C}$; air relative humidity $80.0,68.0,54.0$ and $78.0 \%$, month round accumulated precipitation of $211.5,0.3,3.8$ and $279.0 \mathrm{~mm}$; winds prevailed from the northeast at an average speed of $1.60,1.70,2.10$ and $2.0 \mathrm{~m} / \mathrm{s}$; insolation $7.21,8.3,9.4$ and 4.7 hours, respectively. The north of Minas Gerais State has a climate Aw: tropical of savanna, according to the classification of Köppen, with dry winter and rainy summer (Vianello $\&$ Alves 2000). The areas studied were: pasture 1 (in activity) and pasture 2 (abandoned pasture $=$ savanna in recovery) and their coordinates and altitude are: longitude $43^{\circ} 57^{\prime}$ 31.4"W and $43^{\circ} 53^{\prime} 21.6^{\prime \prime} \mathrm{W}$, latitude $16^{\circ} 46^{\prime} 16.1$ 'S and $16^{\circ} 53$ '45.2"S, and altitude $940 \mathrm{~m}$ and $999 \mathrm{~m}$, respectively. These areas show different characteristics of soil and floristic diversity (see Leite et al. 2011).

As the spherical gall density on $C$. brasiliense leaves is highly variable among trees - (data not published), we chose 10 infested trees (adult plants) per area. To evaluate the distribution of spherical galls within the tree crown we recorded the number of galls on the compound leaves of C. brasiliense of four randomly selected stems positioned (see Leite et al. 2009) on north, south, east, and west facing sides of ten adult trees per area.

To evaluate the distribution of spherical galls among the leaflets we recorded: i) gall abundance according to foliage orientation (slope); ii) the differential abundance of galls on the right, central and left leaflets (Leite et al. 2009); iii) gall abundance on the distal, median, and proximal region of a leaflet (Leite et al. 2009); iv) gall abundance on the leaflet border, central area, and adjacent to the mid leaf vein of the leaflet, and v) difference between areas (Leite et al. 2009). 1,881 leaflets of 627 leaves in pasture 1 and 2,613 leaflets of 871 leaves in pasture 2 were censured for spherical galls.

All data were transformed to $\sqrt{ } \mathrm{x}+0.5$ and were analyzed by analysis of variance and followed by the Tukey test at the significance level $\mathrm{P}<0.05$.

\section{RESULTS}

The smaller number of spherical gall was observed in pasture $1(3.33 \pm 0.47 \mathrm{~B})$ than in pasture $2(5.80 \pm 0.51 \mathrm{~A})$. More spherical galls were found on the northern followed the eastern slopes while fewer spherical galls were found on the foliage in the southern and western slopes in the pasture 1. However, in the pasture 2, the lower spherical galls were observed on the northern than other slopes (Fig. 2).

The average number of spherical galls did not differ statistically among the three leaflets of $C$. brasiliense in the pasture 2 (Fig. 3). However, in the pasture 1, we observed higher number of spherical galls in the central leaflet followed right than the left leaflet (Fig. 3). More spherical galls 
were found in the leaf $1(30.5 \%)$ than leaf position $4(20.8 \%$ of all galls sampled) (Fig. 4).

The average number of spherical galls did not differ statistically among the longitudinal region on leaflet of $C$. brasiliense (Fig. 5). However, the spherical gall insect preferred colonized the leaf margin than the central portion or near mid vein on transversal regions on a leaflet (Fig. 6).

\section{DISCUSSION}

The pasture 1 (in activity) has less floristic diversity $(<$ trees, groves, shrubs and herbs) and more soil covering by grass than pasture 2 - savanna in recovery (Leite et al. 2011). Despite of these areas do not have significant differences in relation density of $C$. brasiliense trees per hectare, these trees are higher in the first pasture (Leite et al. 2011). In addition, the soil in the first area is more acidic, richer in aluminum and less sandy than in the second area (Leite et al. 2011). Perhaps these variables can explain the difference in density of the spherical gall (Eulophidae) in the two pastures.

As Eulophidae insects are generally small, there is a possibility that wind may have played an important role in their within tree distribution. The dispersion of many insects can be influenced by wind direction (Feng et al. 2004, 2005; Leite et al. 2009). As the prevalent winds in the region are northeasterlies/easterlies (data from the Main Climatic Sta-
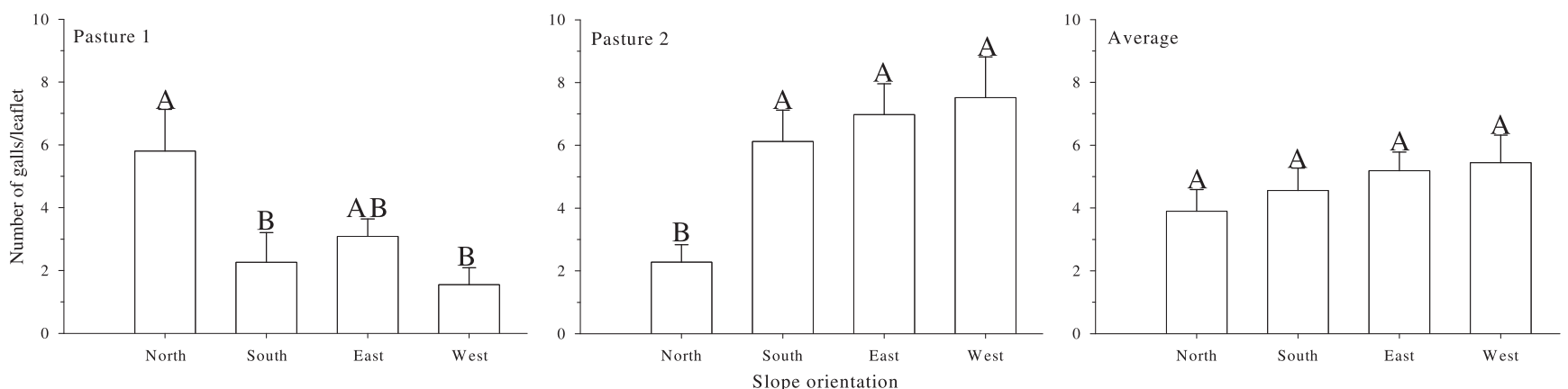

Fig. 2. Number of spheric galls induced according to stem orientation on Caryocar brasiliense leaves. Averages followed by the same letters did not differ statistically at $\mathrm{P}<0.05$ (Tukey test). The bars represent the standard error.
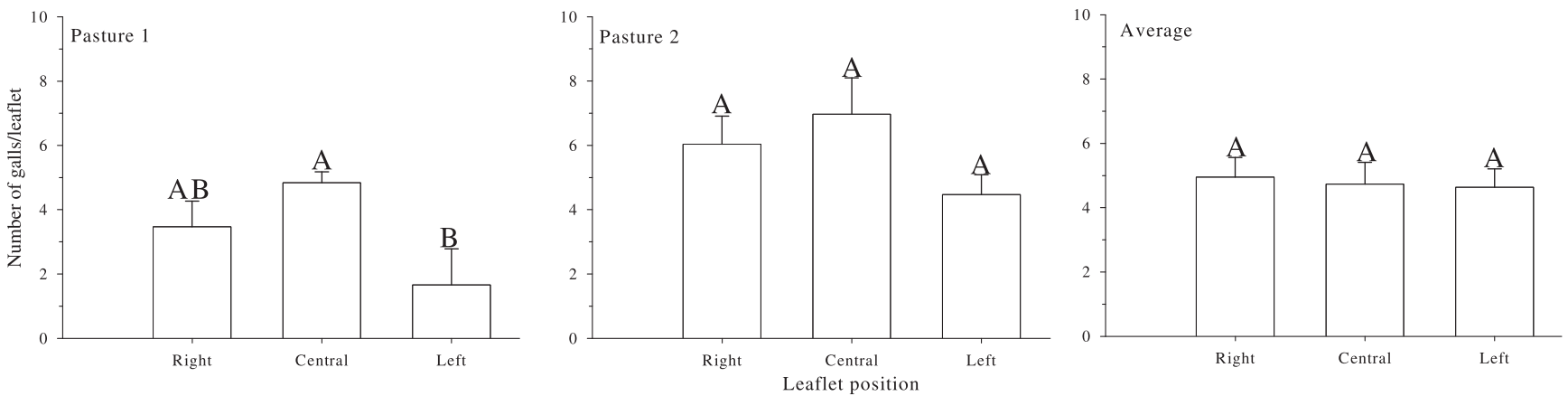

Fig. 3. Number of spheric galls induced according to position leaflet on Caryocar brasiliense leaves. Averages followed by the same letters did not differ statistically at $\mathrm{P}<0.05$ (Tukey test). The bars represent the standard error.
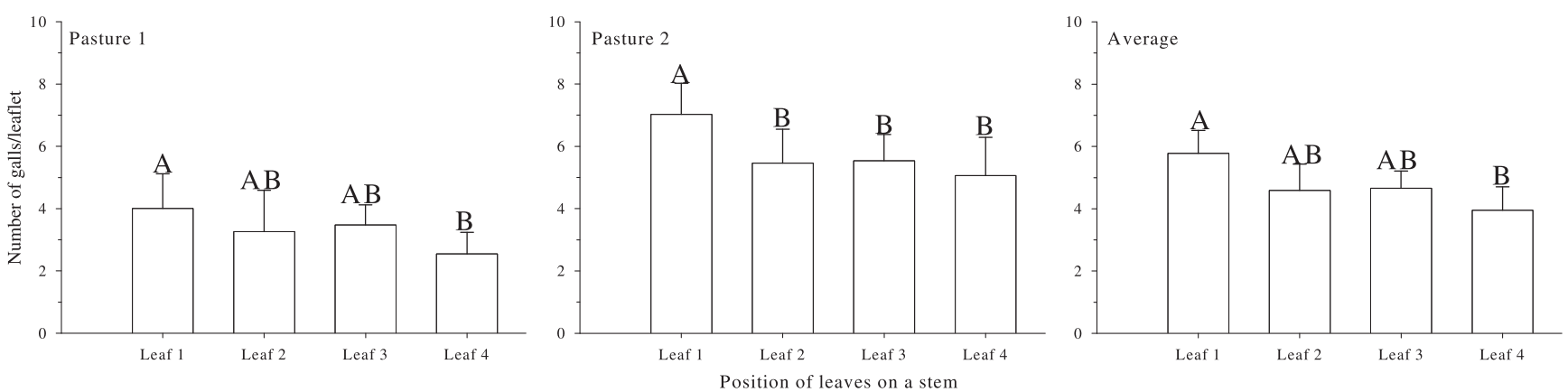

Fig. 4. Number of spheric galls induced according to position leaves on Caryocar brasiliense stem. Averages followed by the same letters did not differ statistically at $\mathrm{P}<0.05$ (Tukey test). The bars represent the standard error. 

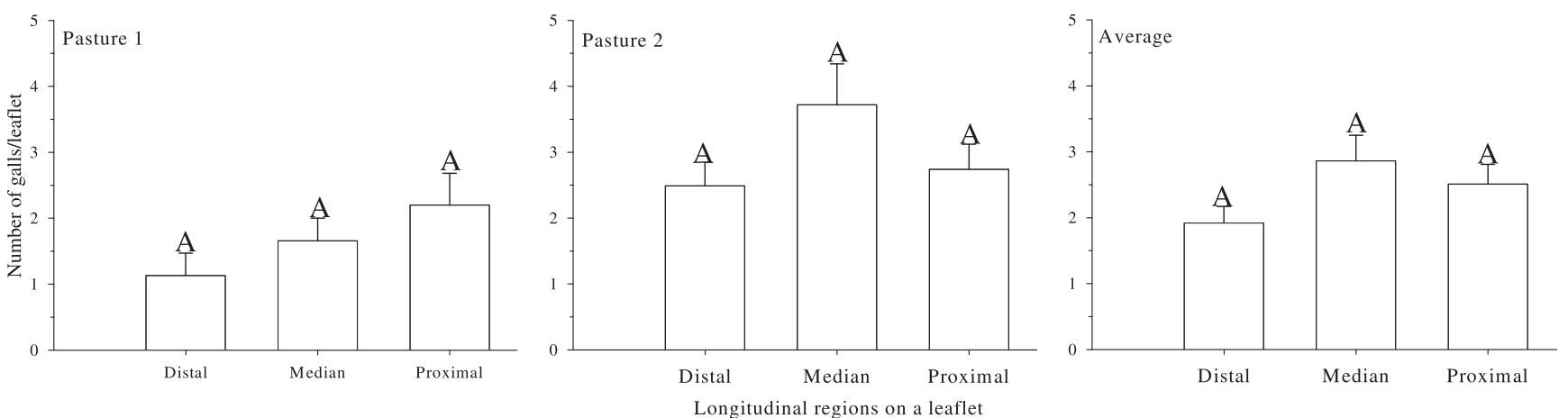

Fig. 5. Number of spheric galls induced according to longitudinal regions on Caryocar brasiliense leaflet. Averages followed by the same letters did not differ statistically at $\mathrm{P}<0.05$ (Tukey test). The bars represent the standard error.
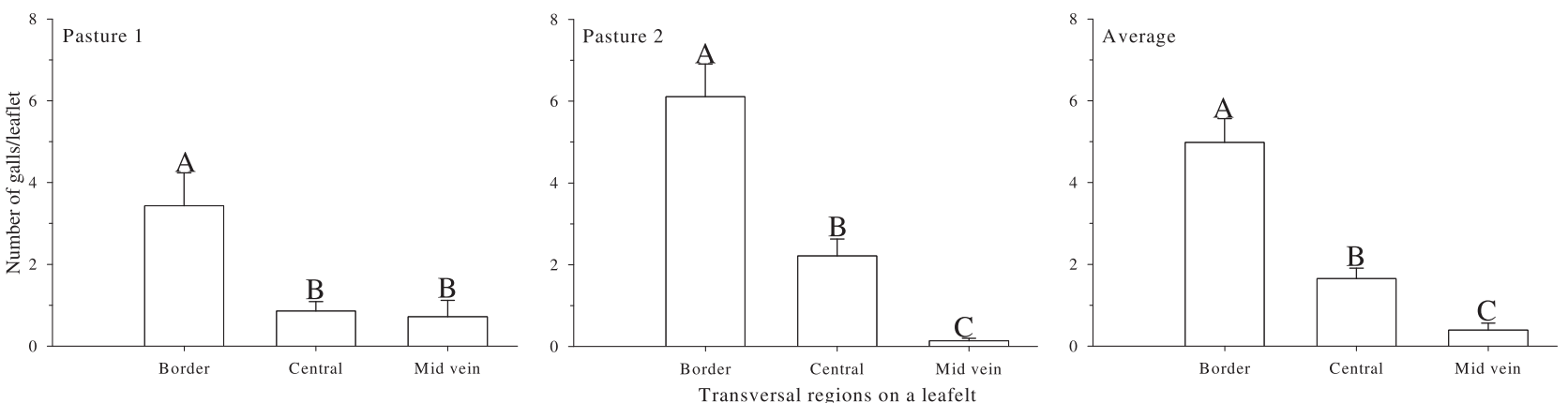

Fig. 6. Number of spheric galls induced according to transversal regions on Caryocar brasiliense leaflet. Averages followed by the same letters did not differ statistically at $\mathrm{P}<0.05$ (Tukey test). The bars represent the standard error.

tion of Montes Claros), we postulate that the foliage on the eastern slope of the host trees are the most exposed to higher winds and strong sunlight. These observations corroborate previous findings in which galling insects are most abundant on sunlight-exposed foliage (Hartman 1984; Fernandes \& Price 1988; Leite et al. 2009).

At smaller scale, no difference in gall abundance was found when the leaflet position was taken into account in the pasture 2. However, in the pasture 1, we observed highest number of spherical galls in the central leaflet maybe due to more interceptation of plant photosynthates. More spherical galls was observed on the leaf margin compared to the other transversal leaf areas maybe due to extrafloral nectarines were also mostly frequent on the leaf margins (Rezende 1998). The role of extrafloral nectarines on the host plant interaction with galling insect is not known. Otherwise, we postulate that they might influence the Eulophidae female preference as they may have an indirect positive role in protecting the galling insects against natural enemies by attracting ants. Ants were reported to be associated with the leaf extraflora nectaries of C. brasiliense (Oliveira 1997).

The evaluations of spherical galls (Eulophidae) and Eurytoma sp. (Eurytomidae) were in the same areas. The data indicate a possible competition between these galling insects, both preferentially attack the leaf margin, which are: a) the pasture 1 had more galls of Eurytoma sp. ( 3/leaflet) (unpublished data) than the pasture $2(\sim 0.3 /$ leaflet, Leite et al.
2009), maybe explaining why we observed more spherical galls in pasture 2 than in the pasture 1 ; b) more Eurytoma galls were found on the eastern slope compared to the other slopes while fewer galls were found on the foliage in the northern slope of $C$. brasiliense (Leite et al. 2009), perhaps justifying why the spherical gall showed different behaviors of colonization in the two pastures; c) galls of Eurytoma sp. were found on the leaves of C. brasiliense in the interior (Leite et al. 2009) while spherical galls more at the border of the tree crown; d) more galls of Eurytoma were found on the median region of the leaf compared to the distal and proximal areas of $C$. brasiliense leaves (Leite et al. 2009) while spherical galls did not differ statistically among the longitudinal region on leaflet; and finally $C$. brasiliense trees more attacked by Eurytoma sp. almost are not colonized by spherical gall (Eulophidae) and we have observed one C. brasiliense tree stronger attacked by spherical galls which is not detected Eurytoma sp., and this tree being visited by us for four years (unpublished data). Perhaps there is a chemical or visual marker for that a specie of gall insect dominate a particular ecological niche (i.e. part of a leaf, branch or even a tree). Other possibility is the genetic differences among $C$. brasiliense plants that can be responsible for this process or even chemical or morphological differentiation in different parts of a leaf or leaf position that occupies a branch or leaf's exposure to the sun/wind, and their relationship with other arthropods (i.e. natural enemies). 


\section{REFERENCES}

Auslander, M.; E. Nevo \& M. Inbar. 2003. The effects of slope orientation on plant growth, developmental instability and susceptibility to herbivores. Journal of Arid Environments 55: 405-416.

De Souza, A. L. T.; G. W. Fernandes; J. E. C. Figueira \& M. O. Tanaka. 1998. Natural history of a gall-inducing weevil Collabismus clitellae (Coleoptera: Curculionidae) and some effects on its host plant Solanum lycocarpum (Solanaceae) in southeastern Brazil. Annals of the Entomological Society of America 91: 404-409.

De Souza, A. L. T.; M. O. Tanaka; G. W. Fernandes \& J. E. C. Figueira. 2001. Host plant response and phenotipic plasticity of a galling weevil (Collabismus clitellae: Curculionidae). Austral Ecology 26: 173-178.

Feng, H. G.; K. M. Wu; D. F. Cheng \& Y. Y. Guo. 2004. Northward migration of Helicoverpa armigera (Lepidoptera: Noctuidae) and other moths in early summer observed with radar in northern China. Journal of Economical Entomology 97: 1874-1883.

Feng, H. G.; K. M. Wu; Y. X. Ni; D. F. Cheng \& Y. Y. Guo. 2005. Highaltitude windborne transport of Helicoverpa armigera (Lepidoptera: Noctuidae) in mid-summer in northern China. Journal of Insect Behavior 18: 335-349.

Fernandes, G. W. \& P. W. Price. 1988. Biogeographical gradients in galling species richness: tests of hypotheses. Oecologia 76: 161-167.

Fernandes, G. W. \& P. W. Price. 1992. The adaptive significance of insect gall distribution: survivorship of species in xeric and mesic habitats. Oecologia 90: 14-20

Fernandes, G. W.; T. G. Cornelissen, R. M. S. Isaias \& A. F. Lara. 2000. Plants fight gall formation: hypersensitivity. Ciência e Cultura 52: 49-54

Fernandes, G. W.; S. J. Gonçalves-Alvim \& M. A. A. Carneiro. 2005. Habitat-driven effects on the diversity of gall-inducing insects in the Brazilian Cerrado. p. 693-708. In: A. Raman; C. W. Schaefer \& T. M. Withers (eds.). Biology, Ecology, and Evolution of Gall-inducing Arthropods. Vol. 2, Science Publishers Inc., 780 p.
Hartman, H. 1984. Ecology of gall-forming Lepidoptera on Tetradymia.1. gall size and shape. 2. plant stress effects on infestation intensity. 3. within-plant horizontal and vertical-distribution. Hilgardia 52: 1-39.

Leite, G. L. D.; R. V. S. Veloso, J. C. Zanuncio, L. A. Fernandes \& C. I. M. Almeida. 2006a. Phenology of Caryocar brasiliense in the Brazilian Cerrado Region. Forest Ecology and Management 236: 286-294.

Leite, G. L. D.; R. V. S. Veloso; A. C. M. Redoan; P. S. N. Lopes \& M. M. L. Machado. 2006b. Artrópodes (Arthropoda) associados a mudas de pequizeiro Caryocar brasiliense Cambess. (Caryocaraceae). Arquivos do Instituto Biológico 73: 365-370.

Leite, G. L. D.; R. V. S. Veloso; A. C. R.Castro; P. S. N.Lopes \& G. W. Fernandes. 2007. Efeito do AIB sobre a qualidade e fitossanidade dos alporques de Caryocar brasiliense Camb. (Caryocaraceae). Revista Árvore 31: 315-320.

Leite, G. L. D.; R. V. S. Veloso; F. W. S. Silva; R. E. M. Guanabens \& G. W. Fernandes. 2009. Within tree distribution of a gall-inducing Eurytoma (Hymenoptera, Eurytomidae) on Caryocar brasiliense (Caryocaraceae). Revista Brasileira de Entomologia 53: 643-648.

Leite, G. L. D.; R. V. S. Veloso; J. C. Zanuncio; S. M. Alves; C. A. D. Amorim, \& O. F. F. Souza. 2011. Factors affecting Constrictotermes cyphergaster (Isoptera: Termitidae) nesting on Caryocar brasiliense trees in the Brazilian savanna, Sociobiology 57: 1-16.

Oliveira, P. S. 1997. The ecological function of extrafloral nectaries: herbivore deterrence by visiting ants and reproductive output in Caryocar brasiliense (Caryocaraceae). Functional Ecology 11: 323330.

Rezende, M. H. 1998. Anatomia dos órgãos vegetativos, da flor e estruturas secretoras de Caryocar brasiliense Camb. (Caryocaraceae). DSc Dissertation. São Paulo, Universidade de São Paulo, 91 p.

Vianello, R. F. \& A. R. Alves. 2000. Meteorologia básica e aplicações. UFV, Viçosa, $467 \mathrm{p}$.

Whitham, T. G. 1978. Habitat selection by Pemphigus aphids in response to resource limitation and competition. Ecology 59: 1164-1176.

Received 9/11/2010; accepted 5/8/2011

Editor: Rodrigo Krüger 